\title{
Correction: Thrombin-Par1 signaling axis disrupts COP9 signalosome subunit 3-mediated ABCA1 stabilization in inducing foam cell formation and atherogenesis
}

Monoranjan Boro · Suresh Govatati • Raj Kumar • Nikhlesh K. Singh • Prahalathan Pichavaram • James G. Traylor Jr • A. Wayne Orr - Gadiparthi N. Rao

Published online: 12 January 2021

(c) The Author(s), under exclusive licence to ADMC Associazione Differenziamento e Morte Cellulare 2021

Correction to: Cell Death \& Differentiation

https://doi.org/10.1038/s41418-020-00623-9
The original version of this article unfortunately contained a mistake in one of the author names. The surname is "Orr", not "Wayne Orr". The original article has been corrected. 